\title{
Complementarities and alignment of information systems management and supply chain management
}

\author{
Christina W.Y. Wong* \\ Institute of Textiles and Clothing, \\ The Hong Kong Polytechnic University, \\ Hung Hom, Kowloon, Hong Kong, China \\ E-mail: tcchris@inet.polyu.edu.hk \\ *Corresponding author
}

\author{
Kee-Hung Lai and T.C.E. Cheng \\ Department of Logistics and Maritime Studies, \\ The Hong Kong Polytechnic University, \\ Hung Hom, Kowloon, Hong Kong, China \\ E-mail: lgtmlai@polyu.edu.hk_E-mail: lgtcheng@polyu.edu.hk
}

\begin{abstract}
Although prior research has generated considerable knowledge on the importance of information systems management (ISM) and supply chain management (SCM) for improving business performance, the findings are at best inconsistent and at worst contradictory. This is because one of the key issues concerning the effectiveness of their implementation - the alignment of ISM and SCM - is under-explored. The lack of understanding on the alignment of ISM and SCM has prevented the full exploitation of their implementation that will contribute to improvements in business performance. Drawing on the organisation theory, this study attempts to:

1 examine the complementarities in the philosophical emphases of ISM and $\mathrm{SCM}$

2 investigate how they could complement each other

3 provide illustrative case examples on the performance implications of alignment and misalignment in their implementation.
\end{abstract}

This study advances knowledge on the alignment of ISM and SCM practices and highlights the importance of recognising the complementarities of ISM and SCM in their implementation efforts.

Keywords: complementarities; information systems management; ISM; supply chain management; SCM; organisation theory.

Reference to this paper should be made as follows: Wong, C.W.Y., Lai, K-H. and Cheng, T.C.E. (2009) 'Complementarities and alignment of information systems management and supply chain management', Int. J. Shipping and Transport Logistics, Vol. 1, No. 2, pp.156-171.

Biographical notes: Christina W.Y. Wong is currently an Assistant Professor in the Business Division, Institute of Textiles and Clothing, The Hong Kong Polytechnic University. Her research papers have appeared in Maritime Economics and Logistics, Transport Reviews, Information \& Management, Omega and others. Her current research interests include information integration for supply chain management and IT-enabled transport logistics. 
Kee-Hung Lai is an Associate Professor with research interest in logistics management in the Department of Logistics and Maritime Studies, The Hong Kong Polytechnic University. He has co-authored three books and his research papers have been accepted or published by various journals such as Industrial Marketing Management, Journal of Business Logistics, Omega and others.

T.C. Edwin Cheng is Chair Professor of Management in the Department of Logistics and Maritime Studies, The Hong Kong Polytechnic University. He is concurrently the Siyuan Chair Professor in Nanjing University, China. He obtained a BSc [Eng] (First Class Honours) from the University of Hong Kong, an MSc from the University of Birmingham, and $\mathrm{ahD}$ and an $\mathrm{ScD}$ from the University of Cambridge. His research interests are in operations management and operations research. He has published over 400 papers in such journals as Management Science, Operations Research and MIS Quarterly, and co-authored five books.

\section{Introduction}

Information systems management (ISM) and supply chain management (SCM) are management practices, each of which has a set of objectives and processes to satisfy the strategic and operational needs of organisations. Organisations employ both ISM and SCM practices in the hope that they can lead them to achieve improvements in performance. Research studies to prove this premise have, however, generated inconsistent and contradictory results. Narasimhan and Kim (2001) found that the utilisation of information systems is not significantly related to supply chain cost reductions and differentiation. In contrast, Frohlich (2002) observed positive links between the integration of information technology (IT) with SCM and e-business performance, such as in the percentage of procurement and sales revenue/turnover conducted through the internet and operational performance, such as delivery time, transaction costs and inventory turnover. Similarly, Mukhopadhyay and Kekre (2002) found that electronic integration between buyers and suppliers enhances operational benefits, in terms of reductions in delayed payment and in the number of orders by credit, for both parties. Nevertheless, some studies have yielded mixed results. For instance, Sanders and Premus (2002) revealed that firms that have adopted a higher level of IT perform better on reductions in supply chain cost and cycle time, but not on product quality. Vickery et al. (2003) observed that IT has a positive direct relationship with supply chain integration, but that the relationship between supply chain integration and financial performance is indirect via customer service. Closs and Savitskie (2003) found that internal logistics information technology (LIT) integration, which is a system that facilitates logistics activities including order processing, inventory control, warehousing and transportation management for supply chain integration, can enhance customer service performance. However, external LIT integration adversely affects customer service performance. 
Prior studies have found inconsistent and contradictory results because the fundamental questions on the implementation of ISM and SCM in organisations have yet to be addressed. Among these, the issues of the alignment of ISM and SCM in their implementation and whether the alignment will lead to improvements in performance have not received due research attention. Particularly, many studies tend to investigate these issues from either the perspective of:

1 the utilisation of ISM to solve SCM problems (e.g., Burbridge, 1988; Gustin et al., 1995, Bowersox and Daugherty, 1995; Roberts and Mackay, 1998; Narasimhan and Kim, 2001; Edwards et al., 2001; Sanders and Premus, 2002; Closs and Savitskie, 2003)

2 the influence of SCM on ISM practices (Hewitt, 1994; Bensaou and Venkatraman, 1995; Cooper et al., 1997b; Lee et al., 1997; Scannell et al., 2000).

A review of literature indicates insufficient recognition of the need to explore the alignment of ISM and SCM and its links with business performance. In this article, we integrate the findings from these two different, but related research streams, identify the complementarities of ISM and SCM and explore the performance implication of aligning them in their implementation.

The alignment of ISM and SCM is important from both academic and managerial perspectives. Although organisations often take ISM into account to leverage SCM for business performance, such initiatives may not necessarily lead to successful organisational outcomes, as the practices of ISM and SCM may not reinforce each other in their implementation (e.g., Edwards et al., 2001). For instance, ISM practices may provide information interchange support between business processes but fail to improve the management of a supply chain. Similarly, SCM practices may be embraced to manage the flows of information, products, finance and knowledge amongst firms in a supply chain, but these practices may be incompatible with the ISM practices deployed in exploiting business opportunities, such as enhancing customer relationship management to better serve the market needs. It is also possible that a firm that manages a complex supply chain involving coordination with multiple supply chain partners may have ISM practices that are unable to support its large-scale supply chain operations. After all, though organisations recognise the importance of implementing both ISM and SCM practices to improve performance, they tend to be unaware of the complementarities of ISM and SCM that can enable them to leverage their ISM resources and capabilities to better meet their supply chain needs (e.g., Pagell, 2004). Alternatively, firms can utilise SCM to overcome the limitations of ISM, e.g., exploiting the lack of external focus by utilising SCM to cultivate relationships with partner firms. In line with this, a study of the chemical industry suggested that the alignment of ISM and SCM is a major management concern. The industry considers that, since a chemical supply chain represents $60-80 \%$ of a typical chemical company's cost structure, a 10\% cost reduction from its supply chain operations can help to yield 40-50\% more of profits (Wood, 1997), but such a goal for cost reduction could fail due to a lack of alignment with ISM.

To explore the alignment of ISM and SCM, following past studies on alignment (e.g., Milgrom et al., 1991; Milgrom and Roberts, 1990; Whittington et al., 1999), we define the alignment of two management practices as the mutual coherence among their elements, e.g., objectives and operations. Prior studies have empirically found that alignment engender better performance than a misalignment (Van de Ven and Drazin, 
1985; Milgrom et al., 1991; Milgrom and Roberts, 1990; Zhu, 2004) and complementarity provides a theoretical lens to understand the alignment of ISM and SCM, which entails that performance is dependent on the congruence between key organisation variables, such as management practices (Whittington et al., 1999). In this study, we explore the complementarities of ISM and SCM in conception and the alignment of ISM and SCM in implementation, within the framework of organisation theory (OT) to advance knowledge on their alignment for business performance (Child, 1972; Venkatraman, 1989b).

Before proceeding to identify the complementarities between ISM and SCM, it is necessary to understand their philosophical emphases. That is, what are the managerial and operational foci of ISM and SCM that may facilitate (hinder) their complementarities, thereby enhancing (undermining) business performance?

\section{Managerial and operational foci of ISM and SCM}

Drawing on OT, we first identify the philosophical emphases of $\mathrm{ISM}^{1}$ and $\mathrm{SCM}^{2}$. OT explains the inter-dependence of organisational resources and management practices that contribute to the adaptability and capability of organisations in managing organisational resources and business environment conditions (Koza and Theonig, 2003). It recognises that both the external environment and internal organisational attributes affect business performance (Das et al., 1991). It is therefore particularly pertinent to apply OT to identify the philosophical emphases of management practices that form and determine the fundamental operations and structure of organisations (Burrel and Morgan, 1979).

In the duality of OT, namely social determinism and freewill, also referred to as determinism and voluntarism respectively, human beings and their institutions are viewed as either influenced and constrained by exogenous forces or conditioned and affected by endogenous attributes. Determinism states that firms are constrained by and are adapting and reacting to the environment and external constraints and forces, e.g., customer demand. In contrast, voluntarism assumes that the management of an organisation has the freewill to decide, choose and implement organisational characteristics, e.g., structure, business strategy, product differentiation and so forth (Astley and Van de Ven, 1983; Burrel and Morgan, 1979). The duality of voluntarism and determinism contributes to the understanding of the theoretical complementarities of two seemingly competing or dichotomised management practices (Pozzebon, 2004). This classical duality from OT can serve as the theoretical foundation to understand the philosophical emphases of ISM and SCM.

Although ISM plays a major role in integrating IT-enabled processes among business partners, ISM often originates from and is conditioned by organisational endogenous attributes, such as company policy and organisational structure (Covin et al., 1990). Although prior studies have suggested that ISM of firms might be associated with institutional pressures, such as supply chain partners and business environment (e.g., Ang and Cummings, 1997; Lai et al., 2006), majority of decisions related to ISM, e.g., IT adoption and systems integration, are made by management and constrained by internal organisational characteristics such as organisational structure as well as the allocation and availability of resources in organisations (Earl, 1993). ISM is subject to organisational choice and to the ability to develop and leverage internal IT resources and capabilities that affect firm performance (Clemons and Row, 1991; Mata et al., 1995). In other words, 
ISM plays a role in the configuration of systems infrastructure and IT resources, which depends on managerial choice, company policy and organisational practices. For instance, a firm may experience institutional pressures from its trading partners and competitors to adopt a new IT to improve operations efficiency. Without IT resources such as information network, IT expertise and identifiable adoption benefits (Lai et al., 2006), the firm is less likely to adopt the IT. As such, managers have free choice to decide and enact ISM for their organisations, while ISM practices are constrained and conditioned by the endogenous attributes of organisations. Therefore, based on the perspective of OT, we argue that ISM falls into the realm of voluntarism.

In contrast, the notion of SCM is by nature deterministic. Determinism of OT implies that human beings and their institutions are affected and constrained by exogenous forces, i.e., deterministic external forces and environmental conditions like customer demand (Biggadike, 1981). Kopczak and Johnson (2003) suggested that SCM is an externally focused management practice that emphasises integration across companies as a way to coordinate and improve the match of supply and demand. SCM is often influenced and determined by supply chain partners and environmental conditions (e.g., Tan et al., 1998; Ellram and Cooper, 1993), as organisations incorporate the:

1 management of upstream and downstream linkages (Kopczak, 1997)

2 coordination of activities in a supply chain (Edwards et al., 2001)

3 formation of alliances with suppliers and buyers (Lee et al., 1997)

4 development of inter-organisational relationships with supply chain partners (Bensaou and Venkatraman, 1995).

All of these activities involve and are influenced by external entities, such as suppliers and customers and marketplace conditions, which are uncertain and relatively uncontrollable by organisations. In other words, SCM is subject to the environmental conditions faced by the firms and the managerial capability by which their partner firms react and respond cooperatively to the supply chain's conditions (Shin et al., 2000). SCM is also related to firms' goals of meeting the needs of multiple partner firms (Kumar and Van Dissel, 1996). Therefore, SCM converges with the realm of deterministic management practices as the SCM practices of firms are constrained and influenced by exogenous forces, which are relatively uncontrollable by firms.

\section{Complementarities of ISM and SCM}

Due to the divergent philosophical emphases of ISM and SCM, if the two management practices are misaligned in their implementation, the deterministic external forces or voluntaristic attributes and constraints in the implementation process may be overlooked. Consequently, organisations with misaligned management practices may suffer from management bias and limitations, which would cause the failure of firms to exploit resources and choices to improve performance (Prahalad and Bettis, 1986). 


\section{Complementarity $1 \quad$ Generate unique organisational capability}

Though many prior studies have argued that ISM contributes to performance improvement and spawns business opportunities (e.g., Porter and Millar, 1985), organisations may have difficulty in sustaining superior performance from ISM as competitors may find it easy to:

1 identify the source of the firm's superiority in performance that is generated by ISM

2 duplicate investments in IT resources by purchasing the same hardware and software and recruiting personnel with the same IT expertise (Clemons and Row, 1991; Mata et al., 1995; Barney, 1991).

SCM complements ISM as it would not be easy for competitors to develop and form the same collaborative relationships with their supply chain partners. SCM covers a variety of partnership and coordination between trading partners, including operations and logistics coordination, partnerships in market research and product development and coordination of customer service. To implement these activities, firms require more than electronic linkages for information sharing with supply chain partners. They need to attain long-term partnership and develop collaborative relationship with their partner firms to reap better business performance. Thus, aligning ISM and SCM can help firms generate unique and idiosyncratic organisational capabilities.

The experience of BellSouth Telecommunications Inc. (BST) illustrates this notion. BST utilises SCM to complement ISM in helping BST's ISM department to manage its IT suppliers. SCM complements ISM in many different areas: supplier selection, supplier management, negotiation and legal activities. In the meantime, SCM helps to cultivate and maintain collaborative and close supplier relationships by managing the processes of purchasing and negotiating with BST's suppliers. By doing so, the ISM department can focus on its technical expertise, while the SCM department utilises its expertise (e.g., supplier management and legal knowledge) to assist with ISM practices in managing the IT suppliers economically and relationship-wise (Anonymous, 1999, Purchasing). Hence, SCM complements ISM by fostering collaborative relationships through improved supply chain coordination (Handfield and Nichols, 1999), which are difficult for competitors to imitate and develop.

\section{Complementarity 2 Avoid management inertia}

As expounded earlier, ISM is constrained by management decisions and knowledge and endogenous attributes. Due to the voluntaristic nature of ISM, management inertia may be a problem for organisations that implement ISM as the dominant management practice for business performance and opportunities, while considering other management practices as secondary and less important for operations. The ecological theory of organisational change states that organisations often suffer from strong inertial pressures arising from management's mental models, e.g., management's belief and knowledge and endogenous elements, e.g., organisational structure. Inertia contributes to the lack of a tendency to make radical changes in organisational strategy and structure in the face of environmental threats and opportunities, e.g., new customer needs, which leads to a failure to respond to changes in environmental conditions, e.g., customer demands (Hall, 1976, 1984; Hannan and Freeman, 1984; Freeman and Hannan, 1983). According to Huff 
et al. (1992), management prefers to maintain the status quo and tends to resist changing strategic choices outside the frame of the current strategy, thus, impeding the enhancement of operations and the exploitation of potentially advantageous management practices for improving performance. To this end, management is likely to overlook important environmental changes and, as a result, appropriate actions are not taken at the organisational level (Hall, 1976, 1984; Hannan and Freeman, 1984), thereby hindering performance improvement.

Aligning ISM with SCM can reduce the peril of management inertia. The deterministic nature of SCM introduces external forces to organisations. These external forces give rise to a mismatch between the internal and external elements of organisations, e.g., internal operations vs. customer demands and exert pressures on current business strategies and operations that prompt the organisations to respond to the external conditions (Huff et al., 1992). As the implementation of ISM is under the influence of institutional pressures (e.g. Lai et al., 2006), external forces induced by SCM contribute to stimulating the need of firms for ISM and overcome the inertia (Huff et al., 1992). For example, Rocketdyne (Boeing's propulsion and power division) and Carruthers Corporation (a pseudonym name of a chemical processor) have demonstrated the benefits of achieving synergy in different management practices. Both companies bring diverse teams of experts from different areas, such as research and development, supply chain, quality system and ISM, to develop new products. The teams are able to break the inertia that is exerted by endogenous forces, such as existing manufacturing processes, by bringing in diverse knowledge and forces from different management disciplines and their concerns. As a result, both companies have successfully developed and brought new products to their markets in shorter development time than they normally do (Majchrzak et al., 2004). In addition to breaking inertia, organisations can handle a higher level of environmental complexity if their repertoire of information is acquired continuously from daily operations, such as from supply chain coordination with external entities. Their ability to exploit such a repertoire improves correspondingly (Galbraith, 1973). Thus, SCM complements ISM by ascribing information inputs to the deterministic environment.

\section{Complementarity 3 Foster a collaborative relationship}

Many firms recognise the benefits of the electronic data interchange and automated routine transactions, which include higher data accuracy that reduces the probability of rework and delay. This is achieved by adopting inter-organisational systems to facilitate information interchange between firms (Zaheer and Venkatraman, 1994). In addition to installing inter-organisational systems, it is necessary to integrate business processes to facilitate coordination amongst firms to attain better performance (Mukhopadhyay and Kekre, 2002). Integration is the process of interaction and collaboration, by which business functions work together in a cooperative manner (Pagell, 2004). Although ISM can enhance the electronic linkages that facilitates information exchange, on its own ISM is less likely to provoke collaborative relationships amongst firms. SCM is required to foster collaborations and develop relationships with trading partners to achieve process integrations across firms (Ellram and Cooper, 1990, 1993); SCM can complement ISM by integrating business processes through improved supply chain relationships amongst partner firms (Handfield and Nichols, 1999). The SCM experience of Toyota and Honda can illustrate this point. Toyota and Honda, two major Japanese automakers, have 
developed partnerships with their US suppliers, which has enabled them to outperform their US competitors, i.e., GM., Ford and Chrysler, in terms of product development time, cost and quality year after year (Liker and Choi, 2004). Other than utilising ISM to facilitate information interchange with suppliers (Sobek et al., 1998), Toyota and Honda outperform their US competitors by building collaborative relationships with suppliers through making great efforts to understand, educate and supervise their suppliers considerably (Liker and Choi, 2004). By doing so, Toyota and Honda and their suppliers integrate their business processes. This benefits both parties with leading to cost reductions and quality improvement. SCM complements ISM and their alignment promotes process integrations across partner firms to facilitate coordination and to benefit from the collaborative supply chain relationship.

\section{Complementarity $4 \quad$ Reduce transaction costs}

Viewed from the perspective of transaction cost theory, which concerns the costs of running a system (Coase, 1937) and the nature of the governance structures that can exist between organisations under various exogenous conditions (Williamson, 1975), SCM can be understood as the management of a complex system or network of firms (Grover and Malhotra, 2003). Transaction cost theory has been found to be relevant to SCM (e.g., Kotha and Swamidass, 2000), as it enables the investigation and understanding of the governance mechanisms between partner firms (Grover and Malhotra, 2003). Transaction costs can be expressed in terms of two major components: coordination costs and transaction risks (Clemons et al., 1993). Coordination costs refer to the costs of accumulating, communicating and processing information (Clemons et al., 1993). Thus, the costs of coordination are likely to be high when communication and information sharing occur across multiple partner firms.

Transaction risks are defined as the risks of trading partner's intentionally misrepresenting or withholding information, or under-performing their agreed-upon responsibilities (Clemons et al., 1993). Transaction risks arise due to opportunism, which refers to the circumstance in which the trading partners in an exchange relationship may be guided by considerations of self-interest and act with guile (Rindfleisch and Heide, 1997). The existence of opportunism gives rise to transaction costs from monitoring behaviour, safeguarding assets and other activities that restrain supply chain partners from engaging in opportunistic behaviour. To reduce the transaction costs of SCM, firms need to utilise additional management practices to help monitor the business activities and performance of other participants in a supply chain (Clemons et al., 1993).

Aligning ISM with SCM in implementation can reduce the transaction costs of supply chains (e.g., Cash and Konsynski, 1985; Malone et al., 1987; Gurbaxani and Whang, 1991). Prior studies have found that ISM plays a significant role in lowering coordination costs by achieving economies of scale in operations, there-by reducing the transaction costs amongst firms (Gurbaxani and Whang, 1991). In particular, the inter-organisational relationships are characterised by the use of tightly coupled operations that are facilitated by ISM (Malone et al., 1987; Gurbaxani and Whang, 1991). The experience of Schlumberger can further illustrate this view. Schlumberger is a leading oilfield services company that supplies technology, project management and information solutions to the international oil and gas industry. It has more than 60,000 employees in 100 countries and the company's costs of handling the procurement of supplies and equipment are enormous. Rather than taking a centralised approach to managing procurement via one 
purchasing office, Schlumberger decided to install electronic procurement systems (a web-based automated procurement system) to facilitate procurement procedures (Ovans, 1999). Employees are able to access and select the items they need from their own desktop computers via the company's intranet. The use of the electronic procurement system has enabled Schlumberger to consolidate purchases and gain better volume discounts from suppliers, thereby enabling the company to reduce transaction costs substantially. On the strategic and process side, the system enables the company to track and monitor overall purchasing activities, which provides information to further improve their procurement efficiency (Ovans, 1999).

Moreover, ISM mends the environmental, partnership and task uncertainties that arise in inter-organisational relationships (Bensaou and Venkatraman, 1995). It fosters rational behaviour that facilitates long-term partnerships in supply chains. ISM contributes to the reduction of coordination costs as it facilitates stable, cooperative and value-added partnerships through information sharing, which can help reduce the uncertainties of operations amongst firms (Clemons and Row, 1991). ISM helps to reduce transaction risks by decreasing the costs of monitoring performance and by providing the information needed to structure more incentive-compatible reward mechanisms (Clemons and Row, 1991). In sum, ISM enables reductions in transaction risks and coordination costs in the context of SCM.

\section{Complementarity $5 \quad$ Balance internal and external foci}

Researchers have argued that both intra- and inter-organisational integration are necessary to achieve the goals of SCM, such as waste reduction, time compression, flexible response and unit cost reduction (Brewer and Sped, 2000; Davis, 1992), which can in turn improve business performance. However, as discussed earlier, SCM is an externally focused management practice that emphasises business processes external to organisations (Kopczak and Johnson, 2003). This characteristic of SCM may promote inter-organisational but not intra-organisational integration for SCM, where the latter is heavily conditioned by endogenous attributes (Wood, 1997). This limited intra-organisational integration can adversely affect the coordination of activities amongst firms (Hammer, 2001). The case of Avon, the world's leading direct seller of beauty products, illustrates this argument. In the 1980s, Avon operated with a decentralised model - it had branches in six countries that operated independently with separate information systems, no overall planning and no shared manufacturing, marketing and distribution (Cohen and Roussel, 2004). In early 2000, Avon realised that there was a mismatch between the companies selling cycle and its supply chain. It therefore re-designed its processes to improve the responsiveness of its supply chain and manufacturing efficiency and to create a centralised planning function and an inventory hub. In addition to building a centralised database for the planning function, Avon held back on the adoption of IT to support supply chain processes and the development of intra- and inter-organisational integration. Although Avon has redesigned its supply chain processes, problems emerged due to the lack of intra-organisational IT integration. Avon had difficulty coping with the need for fast and responsive supply chain operations as the necessary information was not shared in a real-time manner within the organisation. This not only hindered the efficiency of the internal activities but also made the coordination of external activities difficult (Cohen and Roussel, 2004). Due to the sole focus on SCM 
neglecting the contributions of ISM, Avon could not fully reap the benefits of its supply chain redesign effort, inhibiting its performance improvement.

Since ISM converges with the realm of voluntarism, ISM complements the weakness of SCM in being externally focused. As ISM aligns with SCM practices, it promotes a balance of management attention to both endogenous and exogenous elements and highlights the contribution of ISM to the development of intra- and inter-organisational integration to facilitate information flows to coordinate processes within and between firms (Gurbaxani and Whang, 1991; Davis, 1992). In line with this, Avon avoids the pitfalls of lacking ISM to facilitate information interchange. It has therefore begun to develop a global platform to replace the existing disparate systems in different offices of the company and to support the new supply chain processes (Cohen and Roussel, 2004). After all, by rethinking SCM and recognising the importance of ISM for SCM, Avon is able to increase operations efficiency and reduce costs (Cohen and Roussel, 2004).

\section{Complementarity $6 \quad$ Provide information sharing infrastructure}

Bensaou and Venkatraman (1995) found that communication and the sharing of information amongst firms are necessary for developing close collaborative relationships between supply chain partners to achieve effective supply chain integration (also see Whipple et al., 2002; Landeros and Monczka, 1989). ISM provides technical infrastructure that comprises both hardware and software to enable the transferring, storing and processing of data. In other words, the architectural characteristic of ISM complements SCM by providing infrastructural support to integrate processes across a network of multiple businesses and relationships (Mentzer et al., 2001; Lambert et al., 1998; Larson and Halldorsson, 2002). ISM helps prevent information distortion in a supply chain by enabling inter-organisational systems to operate amongst firms in a supply chain (Lee et al., 1997). The experience of Geon, a chemical company based in Ohio, reflect this view. In 1999, Geon decided to focus on the compounding side of the business and divested part of its operations, i.e., the transformation of vinyl chloride monomer (VCM) to resins, to a joint venture with occidental chemical called OxyVinyls. This action led to disastrous outcomes: works were uncoordinated, information was not shared and overheads and duplication were introduced (Hammer, 2001). Geon's order errors rose by $8 \%$, inventories increased by $15 \%$, working capital rose by $12 \%$ and the order-fulfilment cycle time tripled (Hammer, 2001). To rectify the problems, Geon and OxyVinyls connected the processes of both companies by adopting IT to support them. They integrated their forecasting processes, ordering and fulfilment processes and performance measures by utilising an internet platform to facilitate information sharing. By doing so, Geon was able to reduce order error to $0 \%$, inventories declined by $15 \%$ and the order-fulfilment cycle fell back to its earlier level (Hammer, 2001).

Moreover, relying on SCM alone may not be an effective way to achieve the desired supply chain flexibility (Shin et al., 2000), which refers to the adaptability and responsiveness of a supply chain to sudden and unexpected changes in markets and it is one of the critical factors for SCM success (Lee, 2004). Information is the essence that holds together the business activities and ISM facilitates connections between business functions and across organisations for information sharing in a real-time manner (Finley and Srikanth, 2005; Evans and Wurster, 1997). In particular, ISM has been found to enable flexible operations between firms in a supply chain to deal with market uncertainty (Whipple et al., 2002). Thus, aligning ISM with SCM engenders an agile 
supply chain that is responsive to environmental changes. Further to the case of Geon, in addition to integrating its processes with partner firms, Geon went a step further and integrated its processes with its customers. It utilises ISM to manage the inventory of its customers, such that when the inventories of its customers decrease to an agreed-upon level, Geon automatically delivers replenishments. This move allows Geon to save labour and operations costs for both parties, while maintaining close and collaborative relationships with its customers (Hammer, 2001). It also develops a flexible supply chain that is able to react to unexpected changes in the market by sharing information with partner firms in a timely manner.

\section{Conclusions and implications}

This article integrates the two different, but related research issues on ISM and SCM in the literature, i.e., utilisation of ISM to facilitate information flows in supply chains as well as the effects of SCM on ISM practices on the performance of firm, by exploring their complementarities. The case examples, which illustrate the alignment of ISM and $\mathrm{SCM}$ in practice, reveal that:

1 many organisations are implementing ISM and SCM practices separately without recognising their complementarities in implementation

2 organisations that achieve alignment amongst their ISM and SCM practices can reap greater benefits because of their complementarities.

It is apparent from the case examples that the alignment of ISM and SCM is important for improvements in performance due to their complementarities.

Although ISM and SCM have diverse philosophical emphases, their complementarities suggest that the alignment of ISM and SCM in implementation is critical for improving business performance. The complementarities of ISM and SCM enable:

1 the integration of internal and external processes for coordination amongst firms in a supply chain to create value (Earl, 1989)

2 internal IT resources to be leveraged in response to environmental conditions (e.g., customer demand) for improvements in business performance (Sabherwal and Chan, 2001)

3 firms to be more responsive to external changes and internal inefficiencies to achieve superior performance (e.g., Ketchen et al., 1993).

Useful references are provided in this study for managers to recognise how the two management practices can complement one another for better business performance.

Managers should be aware of the problems of the misalignment of ISM and SCM in their implementation and, more importantly, recognise the complementarities of ISM and SCM for improving performance when formulating plans to implement ISM and SCM. In such a case, the ISM practices, which reflect the endogenous and organisational attributes and the SCM practices, which reflect the exogenous and supply chain conditions, are better to be aligned in their implementation. Table 1 summarised the managerial issues that should deserve management attention when firms seek to better implement their ISM and SCM. 
Table 1 Managerial issues in the implementation of ISM and SCM

\begin{tabular}{|c|c|c|}
\hline Issue on & $\begin{array}{c}\text { Problems of misalignment of } \\
\text { ISM and SCM }\end{array}$ & $\begin{array}{c}\text { Alignment of ISM and SCM to alleviate } \\
\text { problems }\end{array}$ \\
\hline \multirow[t]{3}{*}{$\begin{array}{l}\text { ISM-oriented } \\
\text { firms }\end{array}$} & Suffering inertia & $\begin{array}{l}\text { Introducing external forces to stimulate } \\
\text { firms to act and break the inertia }\end{array}$ \\
\hline & $\begin{array}{l}\text { Unable to sustain business } \\
\text { performance }\end{array}$ & $\begin{array}{l}\text { Creating a unique and idiosyncratic } \\
\text { capabilities to sustain business } \\
\text { performance }\end{array}$ \\
\hline & $\begin{array}{l}\text { Being technologically } \\
\text { focused }\end{array}$ & $\begin{array}{l}\text { Establishing collaborative relationship } \\
\text { with trading partners }\end{array}$ \\
\hline \multirow[t]{3}{*}{$\begin{array}{l}\text { SCM-oriented } \\
\text { firms }\end{array}$} & $\begin{array}{l}\text { Incurring transaction costs } \\
\text { and risks }\end{array}$ & Facilitating information sharing \\
\hline & Being externally focused & Mitigating transaction risks \\
\hline & & $\begin{array}{l}\text { Balancing management attention for both } \\
\text { intra- and inter-organisational elements }\end{array}$ \\
\hline
\end{tabular}

\section{References}

Ang, S. and Cummings, L.L. (1997) 'Strategic response to institutional influences on information systems outsourcing', Organization Science, Vol. 8, No. 3, pp.235-256.

Anonymous (1999) 'Purchasing complements internal customer - IT', Purchasing Vol. 127, No. 6, p.46.

Astley, W.G. and Van de Ven, A.H. (1983) 'Central perspectives and debates in organization theory', Administrative Science Quarterly, Vol. 28, No. 2, pp.245-273.

Barney, J.B. (1991) 'Firm resources and sustained competitive advantage', Journal of Management, Vol. 17, No. 1, pp.99-120.

Bensaou, M. and Venkatraman, N. (1995) 'Configurations of interorganizational relationships: a comparison between U.S. and Japanese automakers', Management Science, Vol. 41, No. 9, pp.1471-1492.

Biggadike, R.E. (1981) 'The contributions of marketing to strategic management', Academy of Management Review, Vol. 6, No. 4, pp.621-632.

Bowersox, D.J. and Daugherty, P.J. (1995) 'Logistics paradigms: the impact of information technology', Journal of Business Logistics, Vol. 16, No. 1, pp.65-80.

Brewer, P.C. and Sped, T.W. (2000) 'Using the balanced scorecard to measure supply chain performance', Journal of Business Logistics, Vol. 21, No. 1, pp.75-93.

Burbridge, J.J. Jr. (1988) 'Strategic implications of logistics information systems', Logistics and Transportation Review, Vol. 24, No. 4, pp.368-382.

Burrel, G. and Morgan, G. (1979) Sociological Paradigms and Organizational Analysis, Heinemann, London.

Cash, J.I. Jr. and Konsynsky, B.R. (1985) 'Is redraws competitive boundaries', Harvard Business Review, Vol. 63, No. 2, pp.134-142.

Child, D. (1972) 'Organization structure environments and performance: the role of strategic choice', Sociology, Vol. 6, pp.1-22.

Clemons, E.K. and Row, M.C. (1991) 'Sustaining IT advantage: the role of structural differences', MIS Quarterly, Vol. 15, No. 3, pp.275-292.

Clemons, E.K., Reddi, S.P. and Row, M.C. (1993) 'The impact of information technology on the organization of economic activity: the 'move to the middle' hypothesis', Journal of Management Information Systems, Vol. 10, No. 2, pp.9-35. 
Closs, D.J. and Savitskie, K. (2003) 'Internal and external logistics information technology integration', The International Journal of Logistics Management, Vol. 14, No. 1, pp.63-76.

Coase, R.H. (1937) 'The nature of the firm', Economica, Vol. 4, No. 16, pp.386-405.

Cohen, S. and Roussel, J. (2004) 'Avon gets its (supply chain) makeover', Fortune, Vol. 150, No. 9, pp.178-183.

Cooper, M.C., Ellram, L.M., Gardner, J.T. and Hanks, A.M. (1997b) 'Meshing multiple alliances', Journal of Business Logistics, Vol. 18, No. 1, pp.67-89.

Cooper, M.C., Lambert, D.M. and Page, J.D. (1997a) 'Supply chain management: more than new name for logistics', International Journal of Logistics Management, Vol. 8, No. 1, pp.1-13.

Covin, J., Prescott, J. and Slevin, D. (1990) 'The effects of technological sophistication on strategic profiles, structure and firm performance', Journal of Management Studies, Vol. 27, No. 5, pp.485-510.

Das, S.R., Zhara, S.A. and Warkentin, M.E. (1991) 'Integrating the content and process of strategic MIS planning with competitive strategy', Decision Sciences, Vol. 22, No. 5, pp.953-984.

Davis, T. (1992) 'Effective supply chain management', Sloan Management Review, Vol. 34, No. 3, pp.35-46.

Dearden, J. (1972) 'MIS is a mirage', Harvard Business Review, Vol. 50, No. 1, pp.90-99.

Earl, M.J. (1989) Management Strategies for Information Technology, Prentice Hall, Englewood Cliffs, NJ.

Earl, M.J. (1993) 'Experiences in strategic information systems planning', MIS Quarterly, Vol. 17, No. 1, pp.1-24.

Edwards, P., Peters, M. and Sharman, G. (2001) 'The effectiveness of information systems in supporting the extended supply chain', Journal of Business Logistics, Vol. 22, No. 1, pp.1-27.

Ellram, L.M. and Cooper, M.C. (1990) 'Supply chain management, partnerships and the supplier-third-party relationship', The International Journal of Logistic Management, Vol. 1, No. 2, pp.1-10.

Ellram, L.M. and Cooper, M.C. (1993) 'The relationship between supply chain management and keiretsu', International Journal of Logistics Management, Vol. 4, No. 2, pp.1-11.

Evans, P.B. and Wurster, T.S. (1997) 'Strategy and the new economics of information', Harvard Business Review, Vol. 75, No. 5, pp.71-82.

Finley, F. and Srikanth, S. (2005) '7 imperatives for successful collaboration', Supply Chain Management Review, Vol. 9, No. 1, pp.30-37.

Freeman, J. and Hannan, M.T. (1983) 'Niche width and the dynamics of organizational populations', American Journal of Sociology, Vol. 88, No. 6, pp.1116-1145.

Frohlich, M.T. (2002) 'e-integration in the supply chain: barriers and performance', Decision Sciences, Vol. 33, No. 4, pp.537-556.

Galbraith, J.R. (1973) Designing Complex Organizations, Addison-Wesley, Reading, Mass.

Grover, V. and Malhotra, M.K. (2003) 'Transaction cost framework in operations and supply chain management research: theory and measurement', Journal of Operations Management, Vol. 21, No. 4, pp.457-473.

Gurbaxani, V. and Whang, S. (1991) 'The impact of information systems on organizations and markets', Communications of the ACM, Vol. 34, No. 1, pp.59-73.

Gustin, C.M., Daugherty, P.J. and Stank, T.P. (1995) 'The effects of information availability on logistics integration', Journal of Business Logistics, Vol. 16, No. 1, pp.1-20.

Hall, R.I. (1976) 'A system pathology of an organization: the rise and fall of the old Saturday evening post', Administrative Science Quarterly, Vol. 21, No. 2, pp.185-211.

Hall, R.I. (1984) 'The natural logic of management policy making: its implications for the survival of an organization', Management Science, Vol. 30, No. 8, pp.905-927.

Hammer, M. (2001) 'The super-efficient company', Harvard Business Review, Vol. 79, No. 8, pp.82-91. 
Handfield, R.B. and Nichols, E.L. (1999) Introduction to Supply Chain Management, Prentice Hall, Englewood Cliffs, NJ.

Hannan, M.T. and Freeman, J. (1984) 'Structural inertia and organizational change', American Sociological Review, Vol. 49, No. 2, pp.149-164.

Hewitt, F. (1994) 'Supply chain redesign', The International Journal of Logistics Management, Vol. 5, No. 2, pp.1-9.

Huff, J.O., Huff, A.S. and Thomas, H. (1992) 'Strategic renewal and the interaction of cumulative stress and inertia’, Strategic Management Journal, Vol. 13, special issue: strategy process: managing corporate self-renewal, pp.55-75.

Kearns, G.S. and Lederer, A.L. (2003) 'A resource-based view of strategic IT alignment: how knowledge sharing creates competitive advantage', Decision Sciences, Vol. 34, No. 1, pp.1-29.

Kenneron, W. (1970) 'MIS universe', Data Management, September.

Ketchen, D.L. Jr., Thomas, J.B. and Snow, C.C. (1993) 'Organizational configurations and performance: a comparison of theoretical approaches', Academy of Management Journal, Vol. 36, No. 6, pp.1278-1313.

Kettinger, W.J., Grover, V., Guha, S. and Segars, A.H. (1994) 'Strategic information systems revisited: a study in sustainability and performance', MIS Quarterly, Vol. 18, No. 1, pp.31-58.

King, W.R. (1978) 'Strategic planning for management information system', MIS Quarterly, Vol. 2, No. 1, pp.27-37.

Kopczak, L.R. (1997) 'Logistics partnership and supply chain restructuring: survey results from the US computer industry', Production and Operations Management, Vol. 6, No. 3, pp.226-247.

Kopczak, L.R. and Johnson, M.E. (2003) 'The supply-chain management effect', MIT Sloan Management Review, Vol. 44, No. 3, pp.27-34.

Kotha, S. and Swamidass, P. (2000) 'Strategy, advanced manufacturing technology and performance: empirical evidence from US manufacturing firms', Journal of Operations Management, Vol. 18, No. 3, pp.257-277.

Koza, M.P. and Thoenig, J.C. (2003) 'Rethinking the firm: organizational approaches', Organization Studies, Vol. 24, No. 8, pp.1219-1229.

Kumar, K. and Van Dissel, H.G. (1996) 'Sustainable collaboration: managing conflict and cooperation in interorganizational systems', MIS Quarterly, Vol. 22, No. 2, pp.279-300.

Lai, K-h., Wong, C.W.Y. and Cheng, T.C.E. (2006) 'Institutional isomorphism and the adoption of information technology for supply chain management', Computers in Industry, Vol. 57, No. 1, pp.93-98.

Lambert, D.M. and Cooper, M.C. (2000) 'Issues in supply chain management', Industrial Marketing Management, Vol. 29, No. 2, pp.65-83.

Lambert, D.M., Cooper, M.C. and Pagh, J.D. (1998) 'Supply chain management: implementation issues and research opportunities', International Journal of Logistics Management, Vol. 9, No. 2, pp.1-19.

Landeros, R. and Monczka, R.M. (1989) 'Cooperative buyer/seller relationships and a firm's competitive posture', Journal of Purchasing and Materials Management, Vol. 25, No. 3, pp.9-18.

Larson, P.D. and Hallordsson, A. (2002) 'What is SCM? And where is it?', Journal of Supply Chain Management, Vol. 38, No. 4, pp.36-44.

Lee, H.L. (2004) 'The triple-A supply chain', Harvard Business Review, Vol. 82, No. 10, pp.102-112.

Lee, H.L., Padmanabhan, V. and Whang, S. (1997) 'The bullwhip effect in supply chains', Sloan Management Review, Vol. 38, No. 3, pp.93-102.

Liker, J.K. and Choi, T.Y. (2004) 'Building deep supplier relationships', Harvard Business Review, Vol. 82, No. 12, pp.104-113. 
Majchrzak, A., Malhatra, A., Stamps, J. and Lipnack, J. (2004) 'Can absence make a team grow stronger', Harvard Business Review, Vol. 82, No. 5, pp.131-137.

Malone, T.W., Yates, J. and Benjamin, R.I. (1987) ‘Electronic markets and electronic hierarchies', Communications of the ACM, Vol. 30, No. 6, pp.484-497.

Mata, F.J., Fuerst W.L. and Barney, J.B. (1995) 'Information technology and sustained competitive advantage: a resource-based analysis', MIS Quarterly, Vol. 19, No. 4, pp.487-505.

Mentzer, J.T., Dewitt, W., Keebler, J.S., Min, S., Nix, N.W., Smith, C.D. and Zacharia, Z.G. (2001) 'Defining supply chain management', Journal of Business Logistics, Vol. 22, No. 2, pp.1-25.

Milgrom, P. and Roberts, J. (1990) 'The economics of modern manufacturing: technology, strategy and organization', American Economic Review, Vol. 80, No. 3, pp.511-528.

Milgrom, P., Qian, Y. and Roberts, J. (1991) 'Complementarities, momentum and the evolution of modern manufacturing', American Economic Review, Vol. 81, No. 2, pp.84-88.

Mukhopadhyay, T. and Kekre, S. (2002) 'Strategic and operational benefits of electronic integration in B2B procurement processes', Management Science, Vol. 48, No. 10, pp.1301-1313.

Narasimhan, R. and Kim, S.W. (2001) 'Information system utilization strategy for supply chain integrations', Journal of Business Logistics, Vol. 22, No. 2, pp.51-75.

Ovans, A. (1999) 'E-procurement at Schlumberger', Harvard Business Review, Vol. 78, No. 3, pp.21-22.

Pagell, M. (2004) 'Understanding the factors that enable and inhibit the integration of operations, purchasing and logistics', Journal of Operations Management, Vol. 22, No. 5, pp.459-487.

Porter, M.E. and Millar, V.E. (1985) 'How information gives you competitive advantage?', Harvard Business Review, Vol. 63, No. 4, pp.149-160.

Pozzebon, M. (2004) 'The influence of structurationist view on strategic management research', Journal of Management Studies, Vol. 41, No. 2, pp.247-272.

Prahalad, C.K. and Bettis, R. (1986) 'The dominant logic: a new linkage between diversity and performance', Strategic Management Journal, Vol. 7, No. 6, pp.485-501.

Quinn, F. (1997) 'The payoff', Logistics Management, Vol. 37, No. 11, pp.56-62.

Rindfleisch, A. and Heide, J.B. (1997) 'Transaction cost analysis: past, present and future applications', Journal of Marketing, Vol. 61, No. 4, pp.30-54.

Roberts, B. and Mackay, M. (1998) 'IT supporting supplier relationships: the role of electronic commerce', European Journal of Purchasing and Supply Management, Vol. 4, No. 2-3, pp. $175-184$.

Ross, D.F. (1998) Competing through Supply Chain Management, Chapman and Hall, New York, NY.

Sabherwal, R. and Chan, Y.E. (2001) 'Alignment between business and IS strategies: a study of prospectors, analyzers and defenders', Information Systems Research, Vol. 12, No. 1, pp.11-33.

Sanders, N.R. and Premus, R. (2002) 'IT applications in supply chain organizations: a link between competitive priorities and organizational benefits', Journal of Business Logistics, Vol. 23, No. 1, pp.65-83.

Scannell, T.V., Vickery, S.K. and Dröge, C.L. (2000) 'Upstream supply chain management and competitive performance in the automotive supply chain', Journal of Business Logistics, Vol. 21, No. 1, pp.23-48.

Shin, H., Collier, D.A. and Wilson, D.D. (2000) 'Supply management orientation and supplier/buyer performance', Journal of Operations Management, Vol. 18, No. 3, pp.317-333.

Sobek, D.K. II, Liker, J.K. and Ward, M.C. (1998) 'Another look at how Toyota integrates product development', Harvard Business Review, Vol. 76, No. 4, pp.36-49.

Tan, K.C., Kannan, V.R. and Handfield, R.B. (1998) 'Supply chain management: supplier performance and firm performance', International Journal of Purchasing and Material Management, Vol. 34, No. 3, pp.2-9. 
Van de Ven, A.H. and Drazin, R. (1985) 'The concept of fit in contingency theory', in Research in Organizational Behavior, Vol. 7, CUMMINGS LL and STAW BM eds., pp.333-365, JAI Press, New York.

Venkatraman, N. (1989b) 'Strategic orientation of business enterprises', Management Science, Vol. 35, No. 8, pp.942-962.

Vickery, S.K., Jayaram, J., Droge, C. and Calantone, R. (2003) 'The effects of an integrative supply chain strategy on customer service and financial performance: an analysis of direct versus indirect relationship', Journal of Operations Management, Vol. 21, No. 5, pp.523-539.

Whipple, J.M., Frankel, R. and Daugherty, P.J. (2002) 'Information support for alliances: performance implications', Journal of Business Logistics, Vol. 23, No. 2, pp.67-81.

Whittington, R., Pettigrew, A., Peck, S., Fenton, E. and Conyon, M. (1999) 'Change and complementarities in the new competitive landscape: a European panel study 1992-1996', Organization Science, Vol. 10, No. 5, pp.583-600.

Williamson, O.E. (1975) Markets and Hierarchies: Analysis and Antitrust Implications, The Free Press, New York.

Wood, A. (1997) 'Extending the supply chain', Chemical Week, Vol. 159, No. 25, pp.25-26.

Zaheer, A. and Venkatraman, N. (1994) 'Determinants of electronic integration in the insurance industry: an empirical test', Management Science, Vol. 40, No. 5, pp.549-566.

Zhu, K. (2004) 'The complementarities of information technology infrastructure and e-commerce capability: a resource-based assessment of their business value', Journal of Management Information Systems, Vol. 21, No. 1, pp.167-202.

\section{Notes}

1 ISM is the management practice that is 'an organised method of providing past, present and forecast information relating to internal and external operations. It supports the planning, control and operational function of an organisation by furnishing uniform information in the proper time-frame to assist the decision-maker' (Kenneron, 1970). ISM emphasises information flows that are relevant to the operational and strategic activities of firms (e.g., Dearden, 1972; King, 1978). ISM practices comprise the identification of IT applications, allocation of IT resources and support of IT usage to facilitate operations, e.g., decision making and organisation strategy. Research to date has shown that ISM has a positive impact on business performance in terms of capital return and percentage of market share (e.g., Kettinger et al., 1994; Kearns and Lederer, 2003; Earl, 1993).

$2 \mathrm{SCM}$ is the management practice that seeks synchronisation and convergence of intra- and inter-firm operational and strategic capabilities into a unified and compelling marketing force (Ross, 1998). A supply chain is a network of multiple businesses, involving upstream and downstream flows of products, services and information from different sources to satisfy customer needs (Mentzer et al., 2001; Lambert et al., 1998; Larson and Halldorsson, 2002). SCM extends the concepts of intra-organisational integration beyond a firm to all the firms in a supply chain to develop inter-organisational integration to generate collective efforts to create customer value (Cooper et al., 1997a; 1997b). SCM articulates external relationships and operations with partner firms to streamline cross-company processes to manage the information, products, service, finance and knowledge flows amongst members of a supply chain with the ultimate goals of satisfying customer requirements profitably (Mentzer et al., 2001; Hammer, 2001). SCM represents one of the most significant paradigm shifts in business management by recognising that individual firms no longer compete as solely autonomous entities, but rather as supply chains (Lambert and Cooper, 2000). Many studies have found that the implementation of SCM is positively associated with firm performance (e.g., Quinn, 1997). 